\title{
THE EFFECT OF SERVICE PLACE AND PRICE ON PURCHASE SATISFACTION AND ITS IMPACT ON CUSTOMER LOYALTY OF TRADITIONAL MARKET IN LHOKSEUMAWE CITY
}

\author{
*Mukhlis, Permana Honneyta Lubis, ElvitaMauliana \\ Department of Management, Universitas Syiah Kuala, Indonesia \\ http://doi.org/10.35409/IJBMER.2021.3231
}

\begin{abstract}
This study intends to examine the effect of service placeand purchase satisfaction price and the impact on customer loyalty in the traditional market in the city of Hokseumawe. The population determined in this research is all permanent consumers who are still active in making purchases at the traditional market in Lhokseumawe, totaling 180 people. This research model was tested by Structural Equation Modeling (SEM). The result of research on the traditional market in Lhokseumawe City proves that for the direct effect test: service place and price affect purchase satisfaction, and; service place, price and purchase satisfaction affect customer loyalty. The result of the mediation test proves that purchase satisfaction does not mediate the effect of service place on customer loyalty, and purchase satisfaction does not mediate the effect of price on customer loyalty. The unique finding is that purchase satisfaction does not function as a mediator for service place and price to influence customer loyalty, but only functions as an independent variable to influence customer loyalty. Besides, this tested research model can contribute in particular to the novelty of theory proof. For future researchers, this tested model can be developed by adding other variables such as market image and customer intimacy, which are very closely related to places of business such as traditional market.
\end{abstract}

Keyword: Place Of Service, Price, Purchase Satisfaction, Customer Loyalty.

\section{INTRODUCTION}

The market is often defined as a place where sellers and buyers meet to make buying and selling transactions. The market can be divided into two, namely the modern market and the traditional market. Buyers prefer to shop in places that provide convenience and comfort, both road access to market, market infrastructure, and services provided by sellers/traders.

Lhokseumawe is one of the cities in the State of Indonesia, which is located in Aceh Province. Quoted in BPS Kota Lhokseumawe (2018), the local revenue (PAD) of Lhokseumawe City in 2018 was valued at Rp. 122 billion. Of this figure, approximately more than Rp. 14 billion was contributed by fees paid by traders in the traditional market. In competition with the modern market, the traditional market needs protection. Because so far, retribution from the traditional market has been the biggest contributor to Lhokseumawe City's local revenue. So far, the traditional marketis synonymous with a slum, muddy, and smelly market. 


\section{International Journal of Business Management and Economic Review}

Vol. 4, No. 01; 2021

ISSN: 2581-4664

The Lhokseumawe City Government has provided very adequate facilities and infrastructure for the traditional market. This traditional market in Lhokseumawe City is in the form of a Kiosk and Los. The kiosk is a permanently closed room with a folding door. Los is an open space consisting only of tables without doors and there is no separation between the traders from one another. Lhokseumawe traditional market uses white tiled floors and is clean, so there is no standing water that disturbs the comfort of visitors. This view is sufficient to replace the perception that traditional markets are slums or muddy places.

However, the level of awareness of traditional market users, both from the seller and the buyer, for hygiene is still lacking. This very adequate place will eventually return to a bad image like other traditional markets in general, where the unpleasant smell is caused by scattered garbage, the smell of dried fish blood, and a muddy environment that ultimately causes customers to be reluctant to shop at a traditional market. . Apart from the environmental factors of traditional market and competition with the modern market, competition with mobile traders is also one of the reasons why customers are reluctant to shop at the traditional market where the traveling traders have also provided almost all of the customer's basic needs even to kitchen necessities such as vegetables and fish. This means that customers do not bother to go to the traditional market to shop. Sometimes the peddlers also offer the same or even cheaper prices compared to prices in the traditional market.

Based on the description that has been described above, the authors try to research and find a picture of how the service place and price influence purchase satisfaction and the impact on customer loyalty.

\section{LITERATURE STUDY}

\section{Customer loyalty}

Customer loyalty can be seen from the habits of customers in making purchases or services that are continuous and repeated(Manao, 2020).(Mowen \& Minor, 2017)described customer loyalty is the level where a customer maintains a positive attitude towards the product, has a commitment to the product in the future. Customer loyalty will also create satisfaction for customers, in this case, it will be divided into four categories, namely Failures, Farced loyalty, Defector, and Successes.(Schnaars, 1991). Customer loyalty can be measured using indicators as disclosed by(Kotler \& Armstrong, 2017)as follows: (1) product benefits; (2) product size; (3) product durability; (4) product prices; and (5) Product Marks.

\section{Purchase Satisfaction}

(Zeithaml, Bitner, \& Gremler, 2018)revealed that purchase satisfaction is influenced by service quality, product quality, price, situation factors, and human factors. While(Kotler \& Armstrong, 2017)argued that satisfaction is the level of a person's feelings after comparing the performance of the product (or result) he feels with his expectations. (Blackwell, Miniard, Engel, \& Rahman, 2017)defined satisfaction is as an after-purchase evaluation, that an alternative chosen at least meets or exceeds expectations, so the alternative at least works to meet or exceed expectations, while dissatisfaction is the result of expectations that are negatively affirmed. Purchase satisfaction can be measured by the following indicators(Kotler \& Armstrong, 2017): (1) product delivery; (2) performance; (3) corporate image; (4) brand; and (5) value. 


\section{International Journal of Business Management and Economic Review}

Vol. 4, No. 01; 2021

ISSN: 2581-4664

\section{Place of Service}

(Lupiyoadi, 2013)revealed that the Component concerning location includes the selection of strategic locations (easy to reach). Location relates to decisions made by the company regarding where its operations and staff will be located, the most important of which is the type and level of interaction involved. The location of the service used in supplying services to the intended customer is a key decision(Tjiptono, 2017).According to(Tjiptono, 2017)the place of service can be measured using indicators: (1) access; (2) visibility; (3) traffic; (4) parking facilities; (5) environment; and (6) competence.

\section{Price}

Price is what we get from something that has been sacrificed for the price of obtaining a product or service(Zeithaml et al., 2018). Price according to (Kotler \& Keller, 2018)is the amount of money exchanged for a product or service. The purpose of placing the price according to(Dharmmesta \& Handoko, 2016)is to get maximum profit, maintain the company, achieve a return on investment that has been targeted or return on net sales, control market share, maintain market share. Price measurement can be used using indicators as disclosed by(Kotler \& Armstrong, 2017)are (1) Price affordability; (2) price compatibility with benefits received; (3) price compatibility with facilities; (4) suitability of price and mileage.

\section{Research Paradigm}

Based on the discussion of the problems and research literature, the researcher formulates the research paradigm and hypothesis as follows.

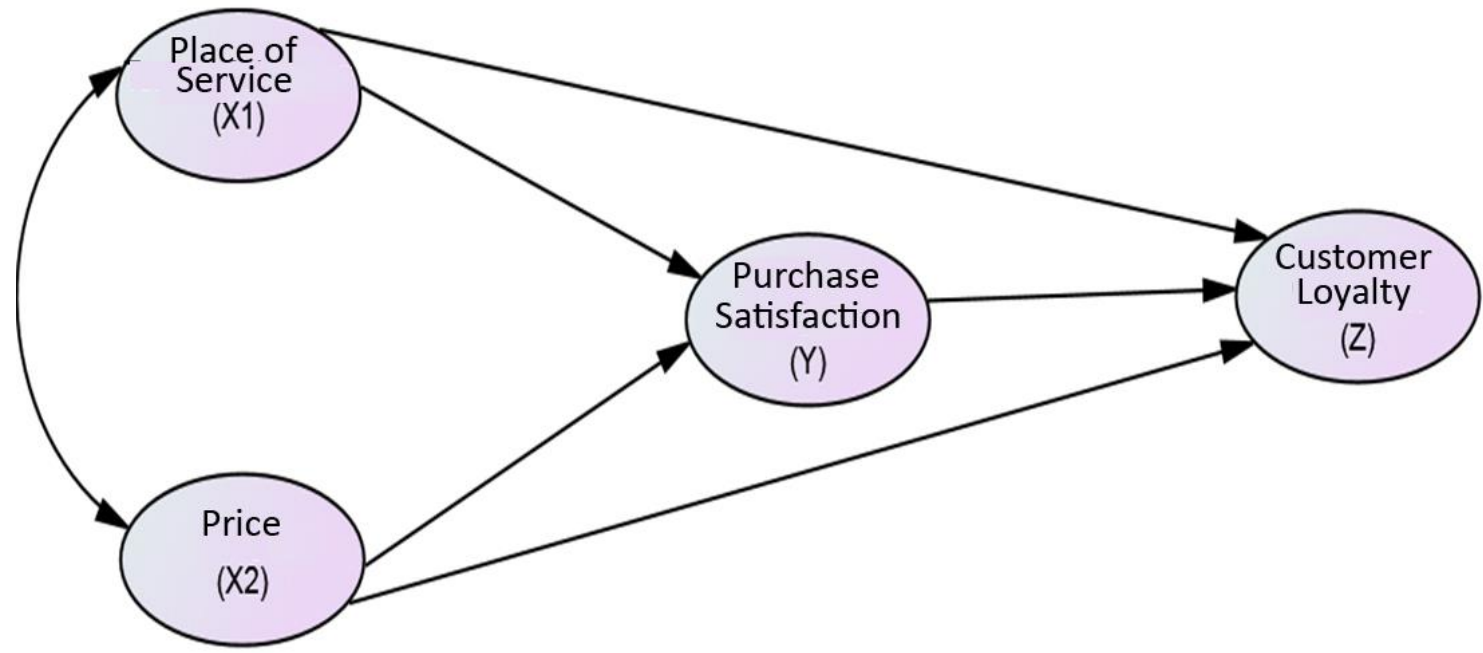

Figure 1. Research Framework

Ha1: service place significantly affects purchase satisfaction

$\mathrm{Ha} 2$ : price significantly affects purchase satisfaction

Ha3: a place of service significantly affects customer loyalty

Ha4: price significantly affects customer loyalty

Ha5: purchase satisfaction significantly affects customer loyalty 


\section{International Journal of Business Management and Economic Review}

Vol. 4, No. 01; 2021

ISSN: 2581-4664

Ha6: a placeof service significantly affects customer loyalty through purchase satisfaction Ha7: Price significantly affects customer loyalty through purchase satisfaction

\section{RESEARCH METHODS}

This research selects objects, namely regular consumers in a traditional market in Lhokseumawe City which is associated with variables of service place, price, purchase satisfaction, and customer loyalty. The population in this research is all consumers in the traditional market in Lhokseumawe City. The sample is a portion of the population that is considered sufficient to represent the population(Arikunto, 2014). In the SEM analysis, the minimum number of samples to be taken is 10 times the number of indicators used(Ferdinand, 2014), so that the minimum sample size in this research is: $10 \mathrm{X} 18$ Indicators $=180$ people.

Data were collected using a questionnaire method, where the list of questions asked provides answers using a Likert scale. The data were analyzed using the Structural Equation Modeling (SEM) technique.(Ferdinand, 2014).SEM can include latent variables in the analysis(Ghozali, 2018).Then mathematically the causality relationship between constructs in research can be stated as follows:

$\eta 1=\gamma 1.1 \xi 1+\gamma 1.2 \xi 2+\zeta 1$

$\eta 2=\gamma 2.1 \xi 1+\gamma 2.2 \xi 2+\beta 21 \eta 1+\zeta 2$

or

Purchase satisfaction $=\gamma 1$. place of service $+\gamma 1.2$ price $+\zeta 1$

Customer loyalty $=\gamma 2.1$ place of service $+\gamma 2.2$ price $+\beta 2.1$ purchase satisfaction $+\zeta 2$

Where:

$\gamma$ : The magnitude of the influence of exogenous latent variables on endogenous latent variables

$\beta$ : The magnitude of the influence of endogenous latent variables on endogenous latent variables $\zeta$ : The magnitude of the error vector in the structural relationship between variables

To test the mediation hypothesis above on the indirect relationship or mediating effect between exogenous and endogenous variables, testing the mediating effect in this research uses a model(Baron \& Kenny, 1986), as shown in the following figure:

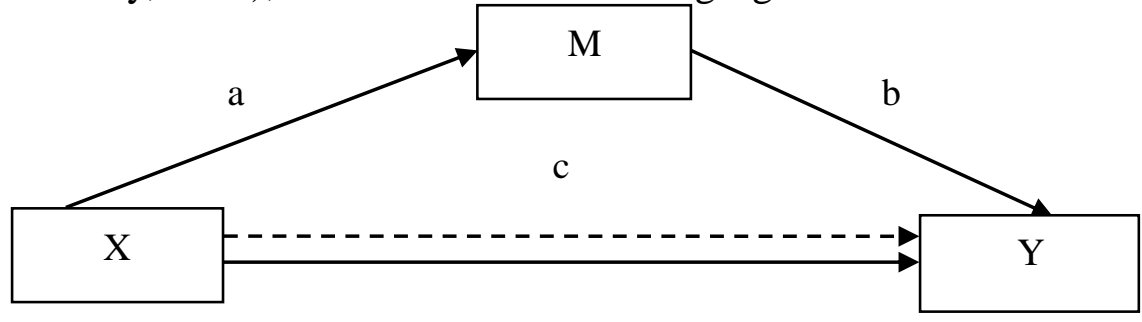

Source: (Baron \& Kenny, 1986)

Figure 2. Testing of Mediation Effects

Testing for the mediation hypothesis is carried out by the method developed by Sobel in 1982 known as the Sobel test (Sobel test). 


\section{International Journal of Business Management and Economic Review}

Vol. 4, No. 01; 2021

ISSN: 2581-4664

\section{RESULTS AND DISCUSSION}

The structural model analysis explaining the effect test between variables is presented in the following path diagram:

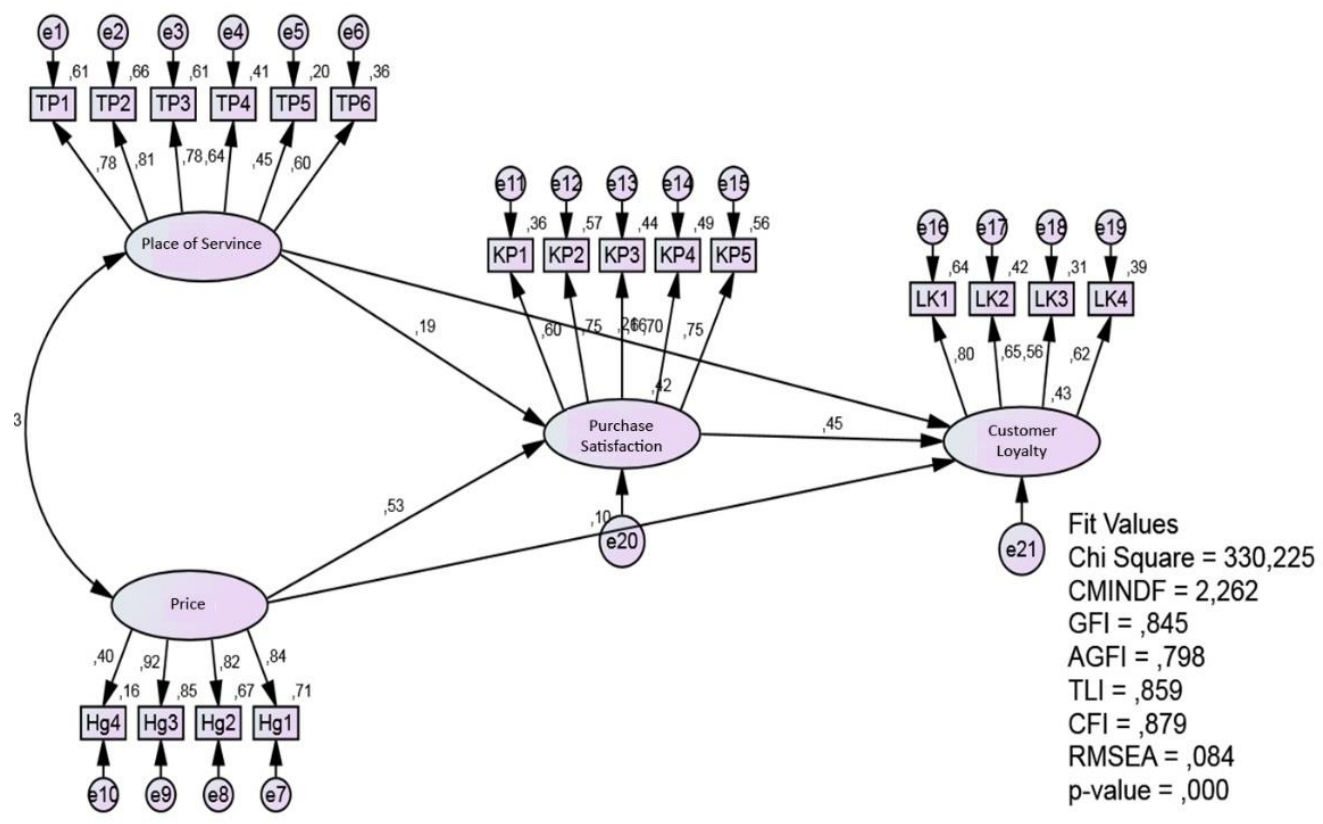

Figure 3. Structural Test Result

The full model test results for testing the direct effect hypothesis after fulfilling the SEM assumptions are more clearly shown in the following table:

Table 1. Direct Effect Hypothesis Test Results

\begin{tabular}{|l|l|l|l|l|l|l|}
\hline Endogenous & & Exogenous & Estimate & S.E. & C.R. & P \\
\hline Purchase Satisfaction & $<---$ & Price & .525 & .067 & 4.947 & .001 \\
\hline Purchase Satisfaction & $<---$ & Place of Service & .193 & .082 & 2.035 & .042 \\
\hline Customer loyalty & $<---$ & Purchase Satisfaction & .451 & .158 & 3.504 & .001 \\
\hline Customer loyalty & $<---$ & Place of Service & .214 & .105 & 2.162 & .031 \\
\hline Customer loyalty & $<---$ & Price & .100 & .089 & 2.143 & .034 \\
\hline
\end{tabular}

Source: Primary data processed

By looking at the test results in table 2, the analysis can be explained as follows:

1. H1: Testing the influence of Service Placeon Purchasing Satisfaction produces a value of C, R. $=2.035 \geq 1.96$, and P-value $=0.042 \leq 0.05$ (criteria Hal accepted). The magnitude of the level of influence between the service place on purchase satisfaction is valued at 0.193 (every improvement in the service place will increase purchase satisfaction). So the results conclude that $\mathrm{Ha} 1$ which states the place of service has a significant effect on purchasing satisfaction in the traditional market of Lhokseumawe City can be accepted. 
Vol. 4, No. 01; 2021

ISSN: 2581-4664

The result of this evidence has the same results as research that has been made by(Atmanegara, Cahyono, Qomariah, \& Sanosra, 2019)(Prayoga, 2019), (Mutmainnah, 2017), (Pangandaheng, 2015), and(Qomariah, 2012)which in their research concluded that there is a significant influence between the image of the company or service place with customer satisfaction.

2. H2: Testing the Effect of Price on Purchase Satisfaction produces the value C, R. $=4,947 \geq$ 1.96 and $\mathrm{P}$-value $=0.001 \leq 0.05$ (criteria for $\mathrm{Ha} 2$ are accepted). As for the level of influence of the price on purchase satisfaction of 0.525 (any improvement in the price will increase purchase satisfaction). Then the results conclude that $\mathrm{Ha} 2$ which states that price has a significant effect on purchase satisfaction is acceptable. The result of this evidence has the same results as research that has been made by(Wijaya, 2017), (Setyo, 2017), (Maulana, 2016),and(Suwarni \& Mayasari, 2011)which in their research concluded that there is a significant influence between the price variable on customer satisfaction.

3. H3: Testing the Influence of Service Place on Customer Loyalty results in the value of C.R. $=2.162 \geq 1.96$ and $\mathrm{P}$-value $=0.031 \leq 0.05$ (criteria Ha3 accepted). The magnitude of the level of influence of the place of service on customer loyalty is valued at 0.214 (every improvement in the service place will increase customer loyalty). So the results conclude that $\mathrm{Ha} 3$ which states the place of service has a significant effect on customer loyalty in the traditional market of Lhokseumawe City can be accepted. The result of this evidence has the same results as research that has been made by(Hermanto, Apriansyah, Fikri, \& Albetris, 2019), (Septiadi, 2015), and(Kandampully \& Hu, 2007)which also states that to achieve loyalty, a satisfying service place is needed. Research conducted by(Andreassen \& Lindestad, 1998)concluded that the place of service perceived by consumers has a significant effect on customer loyalty so that the place of service is a very important variable used in an organization to increase customer loyalty.

4. H4: Testing the Effect of Price on Customer loyalty results in the value C.R. $=2.143 \geq 1.96$ and $\mathrm{P}$-value $=0.039 \leq 0.05$ (criteria $\mathrm{Ha} 4$ accepted). The level of influence of the price oncustomer loyalty is 0.100 (every price improvement will increase customer loyalty). So the results conclude that $\mathrm{Ha} 4$ which states that the analysis of positions has a significant effect on customer loyalty in the traditional market of Lhokseumawe City can be accepted. The result of this evidence has the same results as research that has been made by(Bulan, 2016), (Rotinsulu, Sumayku, \& Sambul, 2015), and(Kurniasih, 2012)which concluded that there is a significant influence between price and customer loyalty.

5. H5: Testing the Effect of Purchase Satisfaction on Customer loyalty produces a value of C.R. $=3.504 \geq 1.96$ and a P-value $=0.001 \leq 0.05$ (criteria for Ha6 are accepted). The magnitude of the level of influence of the purchase satisfaction on customer loyalty is 0.451 (every increase in purchase satisfaction will increase customer loyalty). So the results conclude that Ha6 which states that purchase satisfaction has a significant effect on customer loyalty to consumers of the Lhokseumawe traditional market can be accepted. The result of this evidence has the same results as research that has been made by(Pratama \& Santoso, 2018),(Rachmawati, 2014)stated that purchase satisfaction affects customer loyalty so that if consumers have high purchase satisfaction with their customers, they will be able to increase customer loyalty so that the market will be more effective because purchase satisfaction is a feeling of satisfaction and dissatisfaction of consumers in shopping in the market which is 


\section{International Journal of Business Management and Economic Review}

Vol. 4, No. 01; 2021

ISSN: 2581-4664

described in behavior consumers so that consumer purchase satisfaction is needed by the company to increase sales volume

Furthermore, the mediation test is carried out which can be seen in the following table.

Table 2. Effect coefficients

\begin{tabular}{|c|c|c|c|c|c|}
\hline \multirow[b]{2}{*}{ No } & \multirow[b]{2}{*}{ Description } & \multicolumn{3}{|c|}{ Influence } & \multirow[b]{2}{*}{ Information } \\
\hline & & Direct & Indirect & $\begin{array}{l}\text { Total } \\
\text { effect }\end{array}$ & \\
\hline 1. & $\begin{array}{l}\text { The influence of the service } \\
\text { place variable (X1), the } \\
\text { dependent variables were } \\
\text { customer loyalty (Z) through } \\
\text { purchase satisfaction (Y) }\end{array}$ & 0.214 & 0.087 & 0.301 & Indirect $<$ Direct \\
\hline 2. & $\begin{array}{l}\text { The effect of the price } \\
\text { variable (X2), the dependent } \\
\text { variableswere customer } \\
\text { loyalty }(\mathrm{Z}) \text { through purchase } \\
\text { satisfaction (Y) }\end{array}$ & 0.100 & 0.237 & 0.336 & Indirect $<$ Direct \\
\hline
\end{tabular}

Source: Primary data (processed), 2020

By looking at the test results in table 3, the analysis can be explained as follows:

1. H6: In testing the Influence of the Service Place on Customer Loyalty through Purchase Satisfaction, to know briefly the results of hypothesis testing can be seen in the results of the analysis of the mediation effect using the Sobel test concept as follows:

\begin{tabular}{|c|c|c|c|c|c|}
\hline & Input: & & Test statistic: & Std. Error: & p-value: \\
\hline$a$ & 0.193 & Sobel test: & 0.59037341 & 0.02680676 & 0.55494033 \\
\hline$b$ & 0.082 & Aroian test: & 0.45244789 & 0.03497861 & 0.65094635 \\
\hline$s_{a}$ & 0.214 & Goodman test: & 1.08259806 & 0.01461854 & 0.27898687 \\
\hline & 0.105 & Reset all & \multicolumn{3}{|c|}{ Calculate } \\
\hline
\end{tabular}

Figure 4.Sobel Hypothesis Test Results 6

Based on the picture above shows the calculation results obtained from the calculation of the Sobel test where the statistical test value is 0.590 which is smaller than the required minimum CR value of 1.96 or $(0.590<1.96)$ the $\mathrm{p}$-value is $0.55>0.05$ and a standard error value of 0.001 . These results conclude that the mediating effect of the purchase satisfaction variable on the effect of service place on customer loyalty is not significant. Thus Ha6 was rejected. This means that if customer loyalty needs to be increased, the traditional market of Lhokseumawe City needs to increase the place of customer service and purchase satisfaction (done separately, because each variable only functions as an independent variable which 


\section{International Journal of Business Management and Economic Review}

Vol. 4, No. 01; 2021

ISSN: 2581-4664

only has a direct effect on affect customer loyalty). The result of this evidence is not the same as the results of previous research conducted by(Qomariah, 2012)who stated that the place of service has a significant effect on customer loyalty either directly or indirectly mediated by purchase satisfaction. Customer loyalty refers to customer commitment, a very positive attitude, and is reflected in consistent repurchasing so that loyalty is needed in the consumer.

2. H7: In testing the Influence of Price Consumer on Loyalty through Purchase Satisfaction, to know briefly the results of hypothesis testing can be seen in the results of the analysis of the mediation effect using the Sobel test concept as follows:

\begin{tabular}{|c|c|c|c|c|c|}
\hline & Input: & & Test statistic: & Std. Error: & p-value: \\
\hline$a$ & 0.525 & Sobel test: & 0.74518696 & 0.04720292 & 0.4561587 \\
\hline$b$ & 0.067 & Aroian test: & 0.7322842 & 0.04803463 & 0.46399512 \\
\hline$s_{a}$ & 0.100 & Goodman test: & 0.7587967 & 0.04635629 & 0.44797418 \\
\hline$s_{b}$ & 0.089 & Reset all & \multicolumn{3}{|c|}{ Calculate } \\
\hline
\end{tabular}

Figure 4.Sobel Hypothesis Test Results 7

Based on the picture above shows the calculation results obtained from the calculation of the Sobel test where the statistical test value obtained is a value of 0.745 which is smaller than the required minimum $C R$ value of 1.96 or equal to $(0.7451<1.96)$ p-value. worth $0.45>$ 0.05 and a standard error value of 0.047 . These results conclude that the purchase satisfaction variable does not significantly mediate the price effect of customer loyalty.Thus Ha7 was rejected. This means that if customer loyalty needs to be increased, the traditional market of Lhokseumawe City needs to determine the right prices for its products and must increase purchase satisfaction (done separately, because each variable only functions as an independent variable which only affects. directly in influencing customer loyalty). The result of this evidence is not the same as the results of previous research conducted by (Suwarni \& Mayasari, 2011) said price affects customer loyalty through purchase satisfaction, where the emergence of individual customer loyalty in an organization because the price offered is following the quality of the goods. Price is a reference used by a person in shopping so that he will be shopping somewhere because the price of the goods offered is more affordable by the purchasing power of consumers.

\section{CONCLUSION}

The result of research on the traditional market in Lhokseumawe City proves that for the direct effect test: service place and price affect purchase satisfaction, and; service place, price and purchase satisfaction affect customer loyalty. The result of the mediation test proves that purchase satisfaction does not mediate the effect of service place on customer loyalty, and purchase satisfaction does not mediate the effect of price on customer loyalty. The findings in this research prove that several previous causality theories are still valid today, especially for the traditional market located in Lhokseumawe City. However, the unique finding is that purchase satisfaction does not function as a mediator for service place and price to influence customer loyalty, but only functions as an independent variable to influence customer loyalty. This 


\section{International Journal of Business Management and Economic Review}

Vol. 4, No. 01; 2021

ISSN: 2581-4664

explains that to increase customer loyalty in the traditional market in Lhokseumawe City, service place, price and purchase satisfaction are variables that must be considered and more adjusted to being effective in increasing customer loyalty. This finding is very useful for practitioners, especially those who hold regulations and the market traders of the traditional market in Lhokseumawe city. The indicators of each variable must be considered by regulators and market traders to achieve customer loyalty in the existing traditional market. Besides, the research model that has been tested can contribute in particular to the novelty of theory proof. For future researchers, this tested model can be developed by adding other variables such as market image and customer intimacy, which are very closely related to places of business such as traditional markets.

\section{REFERENCES}

Andreassen, T. W., \& Lindestad, B. (1998). Customer Loyalty and Complex Services. The Impact of Corporate Image on Quality, Customer Satisfaction and Loyalty for Customers with Varying Degrees of Service Expertise. International Journal of Service Industry Management, 9(1), 7-23. https://doi.org/10.1108/09564239810199923

Arikunto, S. (2014). Prosedur Riset suatu Pendekatan Praktik. Jakarta: Renika Cipta.

Atmanegara, S. Y., Cahyono, D., Qomariah, N., \& Sanosra, A. (2019). Pengaruh Kualitas Pelayanan, Citra Perusahaan, Dan Lokasi Terhadap Kepuasan Konsumen Hotel Ijen View Bondowoso. Jurnal Sains Manajemen Dan Bisnis Indonesia, 9(1), 79-89. https://doi.org/https://doi.org/10.32528/jsmbi.v9i1.2375

Baron, R. M., \& Kenny, D. A. (1986). The moderator-mediator variable distinction in social psychological research: Conceptual, strategic, and statistical considerations. Journal of Personality and Social Psychology, 51(6), 1173-1182. https://doi.org/10.1037//00223514.51.6.1173

Blackwell, R. D., Miniard, P. W., Engel, J. F., \& Rahman, Z. (2017). Consumer Behavior (Ed. 10). India: Cengage.

Bulan, T. P. L. (2016). Pengaruh Kualitas Pelayanan dan Harga terhadap Loyalitas Konsumen pada PT. Tiki Jalur Nugraha Ekakurir Agen Kota Langsa. Jurnal Manajemen Dan Keuangan, 5(2), 592-602.

Dharmmesta, B. S., \& Handoko, T. (2016). Manajemen Pemasaran Analisis Perilaku Konsumen. Yogyakarta: BPFE UGM.

Ferdinand, A. (2014). Structural Equation Modeling dalam Riset Manajemen (5th ed.). Semarang: Badan Penerbit Universitas Diponegoro.

Ghozali, I. (2018). Aplikasi analisis multivariate dengan program IBM SPSS 25 (9th ed.). Semarang: Badan Penerbit Universitas Diponegoro.

Hermanto, Apriansyah, R., Fikri, K., \& Albetris. (2019). Pengaruh Lokasi dan Kualitas Pelayanan Terhadap Loyalitas Konsumen pada Fotocopy Anugrah Rengat. Ekonomis: Journal of Economics and Business, 3(2), 171-176.

Kandampully, J., \& Hu, H. (2007). Do hoteliers need to manage image to retain loyal customer? 


\section{International Journal of Business Management and Economic Review}

Vol. 4, No. 01; 2021

ISSN: 2581-4664

International Journal of Contemporary Hospitality Management, 19(6), 435-443. https://doi.org/10.1108/09596110710775101

Kotler, P., \& Armstrong, G. (2017). Principles of Marketing (17th ed.). London: Pearson.

Kotler, P., \& Keller, K. L. (2018). Marketing Management, Global Edition (15th edition). Harlow, United Kingdom: Pearson.

Kurniasih, I. D. (2012). Pengaruh Harga Dan Kualitas Pelayanan Terhadap Loyalitas Pelanggan Melalui Variabel Kepuasan (Studi Pada Bengkel Ahass 0002-Astra Motor Siliwangi Semarang). Jurnal Administrasi Bisnis, I(1), 37-45.

Lupiyoadi, R. (2013). Manajemen Pemasaran Jasa Berbasis Kompetensi (3rd ed.). Jakarta: Salemba Empat.

Manao, A. (2020). Pengaruh Pelayanan Terhadap Loyalitas Pelanggan pada Salon Lideo. Jurnal Education and Development, 8(2), 301-303.

Maulana, A. S. (2016). Pengaruh Kualitas Pelayanan Dan Harga Terhadap Kepuasan Pelanggan PT. TOI. Jurnal Ekonomi, 7(2), 113-125.

Mowen, J. C., \& Minor, M. (2017). Consumer Behavior (Ed. 5). New Jersey: Prentice Hall; Subsequent edition.

Mutmainnah. (2017). Pengaruh Kualitas Layanan dan Citra Perusahaan Terhadap Kepuasan dan Loyalitas Nasabah. Jurnal Manajemen Dan Pemasaran Jasa, 10(2), 201-216. https://doi.org/http://dx.doi.org/10.25105/jmpj.v10i2.2344

Pangandaheng, F. (2015). Pengaruh Kualitas Layanan Dan Citra Perusahaan Terhadap Kepuasan Pelanggan Dan Dampaknya Terhadap Loyalitas Pelanggan Pada PT. Hadji Kalla Palu. Katalogis, 3(2), 51-67.

Pratama, D. W., \& Santoso, S. B. (2018). Pengaruh Citra Merek, Kualitas Produk dan Harga Terhadap Keputusan Pembelian melalui Kepercayaan Konsumen pada Produk Stuck Original. Diponegoro Journal of Management, 7(2), 139-149.

Prayoga, D. W. (2019). Pengaruh Kualitas Layanan Dan Citra Perusahaan Terhadap Kepuasan Layanan Bpjs Ketenagakerjaan Purwakarta. Jurnal Ekonomi Manajemen, 5(2), 69-77. https://doi.org/https://doi.org/10.37058/jem.v5i2.939

Qomariah, N. (2012). Pengaruh Kualitas Layanan dan Citra Institusi terhadap Kepuasan dan Loyalitas Pelanggan (Studi pada Universitas Muhammadiyah di Jawa Timur). Jurnal Aplikasi Manajemen, 10(1), 177-187.

Rachmawati, R. (2014). Pengaruh Kepuasan Terhadap Loyalitas Pelanggan. Jurnal Teknologi Busana Dan Boga, 1(1), 66-79. https://doi.org/ttps://doi.org/10.15294/teknobuga.v1i1.6404

Rotinsulu, E., Sumayku, S., \& Sambul, S. (2015). Pengaruh Harga, Produk Dan Promosi Terhadap Loyalitas Konsumen Big Jay Family Karaoke. Jurnal Administrasi Publik, 2(29), 114.

Schnaars, S. P. (1991). Marketing strategy: a customer-driven approach. New York: The Free Press. 


\section{International Journal of Business Management and Economic Review}

Vol. 4, No. 01; 2021

ISSN: 2581-4664

Septiadi, E. (2015). Pengaruh Lokasi, Pelayanan, Dan Kepuasan Terhadap Loyalitas Pelanggan Warung Seafood "Yu Yem" Pantai Jatimalang. SEGMEN Jurnal Manajemen Dan Bisnis, 11(2A), 1-15. https://doi.org/https://doi.org/10.37729/sjmb.v11i2A.3956

Setyo, P. E. (2017). Pengaruh Kualitas Produk Dan Harga Terhadap Kepuasan Konsumen Best Autoworks. Peforma, 1(6), 755-764.

Suwarni, \& Mayasari, S. D. (2011). Pengaruh Kualitas Produk dan Harga terhadap Loyalitas melalui Kepuasan Konsumen. Jurnal Ekonomi Bisnis, 16(1), 76-84.

Tjiptono, F. (2017). Strategi pemasaran (4th ed.). Jakarta: Andi.

Wijaya, C. V. (2017). Pengaruh Harga, Kualitas Pelayanan Dan Kualitas Produk Terhadap Kepuasan Konsumen Depot Madiun Masakan Khas Bu Rudy. Agora, 5(1), 1-8.

Zeithaml, V., Bitner, M. J., \& Gremler, D. (2018). Services Marketing: Integrating Customer Focus Across the Firm (7th ed.). New York: McGraw-Hill. 